\title{
Analyzing the Jobless Recovery Phenomenon in the Nigerian Economy
}

\author{
Ejiro U. Osiobe \\ The Ane Osiobe International Foundation \\ Odezi M. Oseghe \\ The Ane Osiobe International Foundation
}

This study examines jobless recovery and its effect on Nigeria's economy. The underlying objective of this paper is to evaluate the trend between the increasing gross domestic product and the rate of unemployment in Nigeria. To empirically analyze the impact of the jobless recovery in the nation, we estimated a twostage least square regression from 1986 to 2018, and our results support the view that the increasing real gross domestic product in the nation is associated with the country's jobless recovery status.

Keywords: jobless recovery, Business Cycle Theory, unemployment rate

\section{INTRODUCTION}

Every economy experiences bearish and bullish times according to the Business Cycle Theory (BCT) building on (Lucas, 1980) work; this paper will define BCT as the economic expansion, peak, recession, trough, and recovery. The recovery, expansion, and peak periods are characterized by economic growth, increased productivity, and low unemployment rate while the recession and trough period are the exact opposite. An economy is declared to be in a recession when the economy's Real Gross Domestic Product (RGDP) reduces consecutively for two quarters. However, when an economy experiences a positive relationship with RGDP and unemployment rate, that country is said to be in a jobless recovery state. The relationship between growth, poverty, and inequality has been the focus of economic growth theory and the interest of many scholars' such as ((Romer, $1989 \& 1990)$, (Osiobe, 2019) (Mankiw et al., 1992), (Lucas, 1988), and (Fosu \& Gafa, 2020)).

Fosu \& Gafa (2020) found that the poverty level in Africa has declined over the past few decades due to the rise in Real Gross Domestic Product per capita $R G D P_{\text {per capita }}$, which is consistent with the global economy. Inequality, which this study will use the GINI index as a proxy, is defined as the extent to which the distribution of income and consumer expenditure among individuals and households within an economic region diverge from an equilibrium distribution state (World Development Index (WDI), 2020). This index is appropriate because it is the primary driver of changes in poverty within a community and, has played a significant and complementary role in economic growth and income (re)distribution in some countries like Kenya, Nigeria, Ghana, and South Africa, with a GINI of 40.8, 43.0, 43.5, and 63.0, respectively (WDI, 2020).

Our study builds on (Mbaku, 2020) by aiming to blend the general and specific in probing the complex issue of Nigeria's jobless recovery. While also contributing to the literature on Nigeria's economic growth 
theory and empirically analyzing the socio-economic impact of the nation's jobless recovery, critically examining the widespread optimism about Africa rising (Frankema \& Waijenburg, 2018) and probe the rising problem of inequality and precarious work environment in Africa. Nigeria's economy is a prime case study because the country had some compelling economic indicators in the last fiscal cycle. These indicators include but are not limited to the nation's RGDP growth of $2.3 \%$ in 2019, an inflation rate of $11.3 \%$, fiscal revenue of $7 \%$ below the country's Gross Domestic Product (GDP), increased public spending financed mainly by borrowing, a public debt of 83.9 Billion (bn) United States Dollars (USD) (68\% domestic and $32 \%$ foreign), which is $14.6 \%$ higher than 2018 , and a poverty rate higher than the national average of $69 \%$ in rural communities (Africa Development Bank Group (ADBG), 2020).

According to ADBG (2020), the status quo of the Nigerian economy can be attributed to the low skill limit opportunities for employment in the mainstream economy. In Nigeria, incongruous with the western world economic recovery, the rate of unemployment has been increasing. A prolonged jobless recovery seems unrealistic because, in most recovery periods, the unemployment rate reduces, consumer confidence increases, M1 \& M2 money supply increases (((M1) monies that are the most liquid example (e.g.), cash and debit cards) ((M2) monies that are less liquid, e.g., stocks)), and aggregate demand increases; promoting economic growth. Weller (2014) corroborates this, stating that the labor market and industries pivot towards economic recovery after a recession. The study aims to evaluate the effect of the jobless recovery phenomenon in the Nigerian economy by using a Two-Stage Least Square (2SLS). Our result shows that increasing $\ln R G D P_{t}$ and $\ln P o p \_t$ will hurt the nation $U R_{t}$. The $2 S L S$ results imply that the quality and type of work are central to the growth rate of inequalities in Nigeria. The International Labor Organisation (ILO) decent work agenda established a utile measuring scale for labor at the international level (ILO, 2020). According to Obeng-Odoom (2014), Africa, on the rise, is the new persona that is replacing the negative image of the continent. The re-imaging of Africa has generated considerable interest among scholars that the region has been the center of the world's socio-economic crisis jokes. Mackett (2020) found that higherpaid professionals tend (not always) to have a decent occupation compared to low-skilled workers in elementary occupations. On the other hand, the higher a person is on the occupational ladder, the lower the individual scores in other economic indicators, such as decent working time and balancing work-familyand-personal life and vice-versa.

\section{The Concept of Jobless Recoveries}

The United Nations Development Program (UNDP, 1993) defines jobless growth as a phenomenon in which an increase in employment lags far behind an increase in output. Thus, jobless growth refers to a situation whereby the growth in real GDP moves at a faster rate than the growth in employment. In other words, as GDP grows, the unemployment rate is also on the rise. In 1996, the UNDP gave a broader view on jobless growth as growth in output that generates little or no employment, suppresses wages, makes working conditions dreary, and brings about precarious livelihoods.

\section{Study Area}

Nigeria is a nation located in West Africa with 36 states and the Federal Capital Territory (FCT) and a population size of 195 Million ( $\mathrm{mn}$ ) people as of 2018 (WDI, 2020). The FCT lies between latitude $8^{\circ} 25^{\prime}$ and $9^{\circ} 25^{\prime}$ North of the equator and longitude $6^{\circ} 45^{\prime}$ and $7^{\circ} 45^{\prime}$ East of the Greenwich meridian. It is located in the middle belt of Nigeria (Osiobe, 2018). 


\section{FIGURE 1}

\section{MAP OF NIGERIA SHOWING THE FCT, ABUJA MUNICIPAL AREA, AND GWAGWALADA AREA}

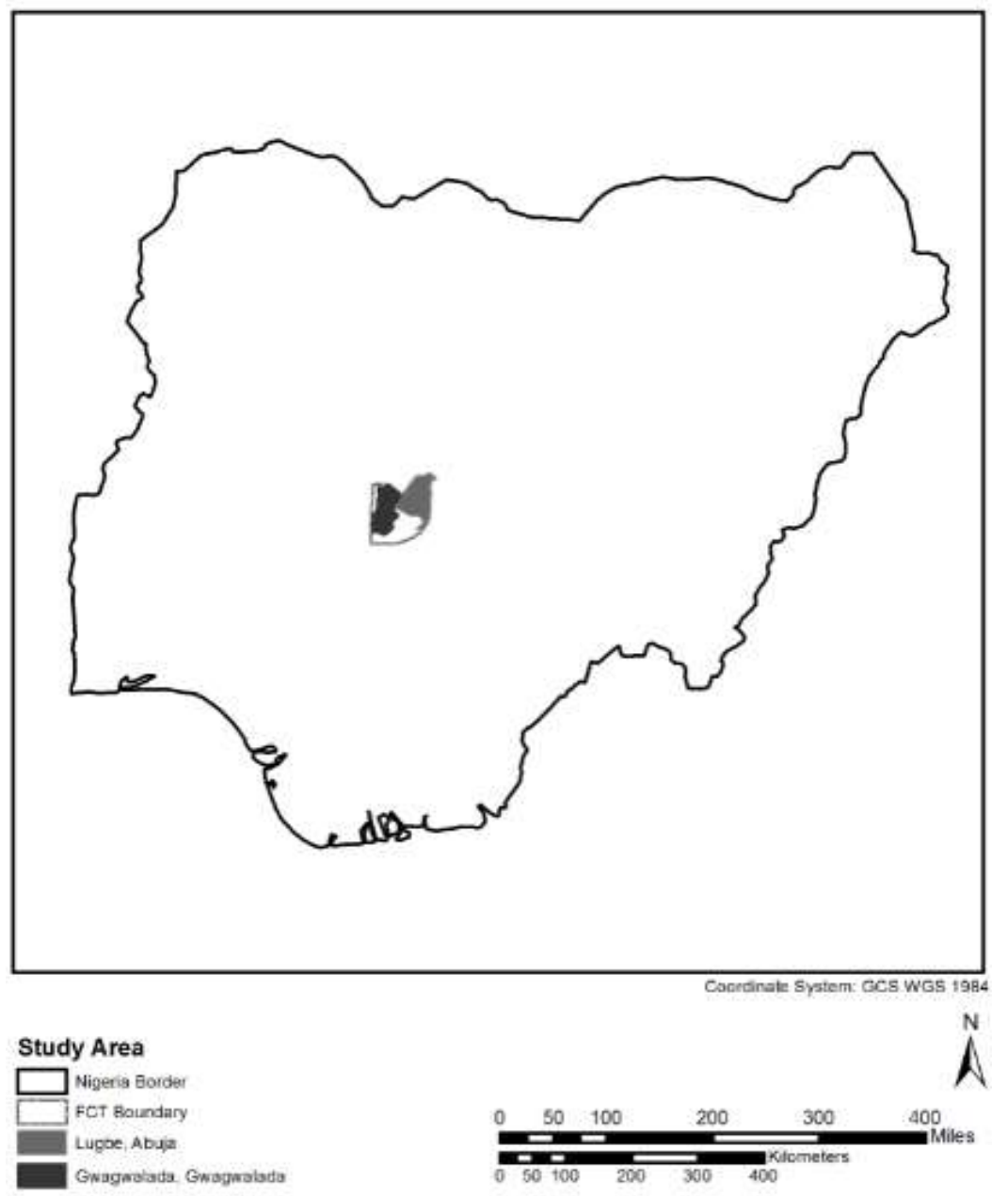

The country is multicultural, with over 250 ethnic groups, with Hausa, Igbo, and Yoruba as the largest ethnic groups with over 500 unique native languages. According to the (WDI, 2020), it is an emerging nation and the regional power of Africa.

\section{LITERATURE REVIEW}

Graetz and Michaels (2017) state that since the early 1990s, recoveries from recessions in the United States (US) have been associated with weak employment growth. According to them, a possible explanation for these jobless recoveries is founded in technological change. The study adopted data on recoveries from 71 recessions in 28 industries and 17 countries from 1970-2011. The aim was to compare the US jobless recoveries with those of other developed countries who had a good technology base. The results suggest that though GDP recovered more slowly after recent recessions, the employment rate did not. The authors' findings indicate that technology is not the cause of jobless recoveries in developed countries outside the US.

Sanusi (2012), examines the dynamic relationships that exist between output growth and unemployment in Nigeria. The study employed a generalized method of moments and linear estimation on 
data for the period 1970-2010. The results from the linear estimates point that the short-run relationship between output and unemployment is negative, but in the long-run, it is positive. This result, therefore, provided support for the hypothesis of non-linearity in the dynamic relationship between output and unemployment and confirmed that the dynamic relationship is non-linear and hump-shaped.

Samavati and Stumph (2004) examine the effect of the 2003-2004 jobless recovery on income and poverty in the US. The study shows a disproportionate number of single mothers and children make up the poor class; the paper went on to study the effect of declining income and arise in the overall poverty rate on the most vulnerable groups in the society (minorities, women, and children). The findings suggest that jobless growth worsened the rate of poverty.

\section{Workforce Flow Chart}

Figure 2 shows the workforce flow chat of any economy. For our study, we will assume that the Total Population $\left(T_{P_{o p}}\right)$ to be $190 \mathrm{Mn}$ people, which is the starting point of the flow. Within the population sample, an economy will have the Dependent Population $\left(D_{P}\right)$, which are people within the age groups of $(0-15$ years $(\mathrm{yrs}))$ and the older people, which are persons' within the ages of (65+yrs). Within the total population sample, an economy also has the Institutionalized Group $\left(I_{G}\right)$ that comprises of people who are in correctional academies, prisons, and hospitals. To get the adult population or labor force, we utilize equation (1):

$T_{\text {Pop }}-\left(D_{P}+I_{G}\right)=$ Adult population/labor force

The labor force is made of the population group within the age group of (16-64 yrs). The labor force is employed (worked at least one hour in the previous week) and unemployed (people actively looking for a job within the past four weeks). The final is the retired population, students, family members like househusbands that help with house chores, and the discouraged group. From 1970-1998, Africa's poverty rose by $55 \%$ from $11 \%$ to $66 \%$ despite a period when foreign aid inflows were at its highest level. But Foreign aid may be beneficial as a palliative, when targeted at specific, narrow objectives, such as the prevention and eradication of diseases like malaria, tuberculosis, HIV/AIDS, smallpox, diarrhea. Other economic woes that have plagued Africa nations include but are not limited to lack of decent work-(place), attractive investment opportunities, capital flight, and minimum risk high-interest investment in western countries. The United Nations (UN) coined the term decent work, and the decent work agenda was not only to establish a definition of good practice, which can be used as a yardstick for workers, but also to create unity among workers, governments, and employers (Mackett, 2020).

The decent work agenda is based on the understanding that works is not only a source of income but more importantly a source of personal dignity, family stability, peace in [the] community, and economic growth that expands opportunity for productive jobs and employment" (Cohen \& Moodley, 2012). The growing popularity of the term also suggests the importance of moving labor market debates beyond the employment/unemployment discussion. This is especially important, given that in many countries, labor market wages are the primary source of income. Thus, indicating that inequality in the quality of jobs and the subsequent wages and opportunities derived from them will also translate to broader inequalities within the society. 


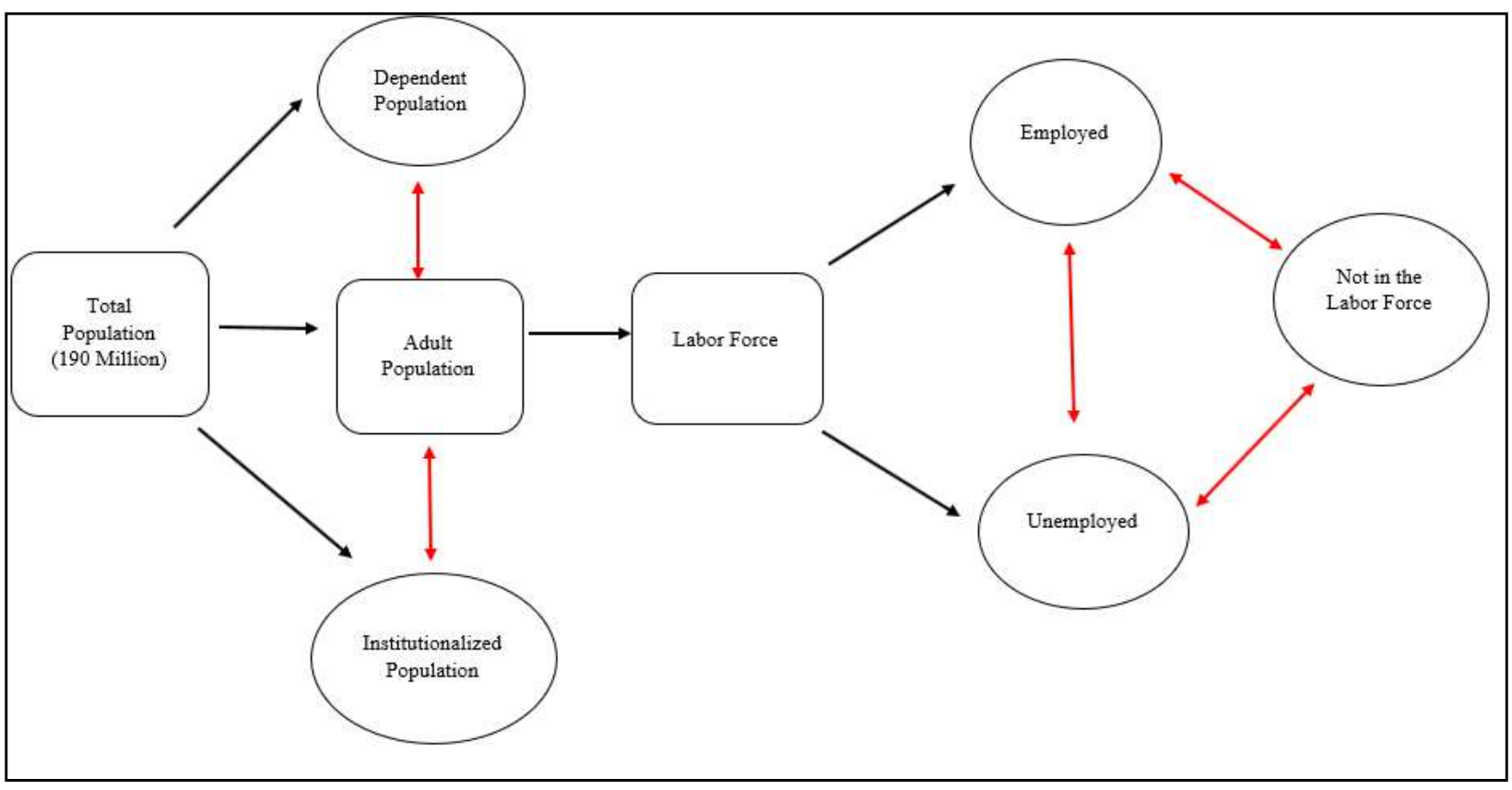

\section{METHODOLOGY}

\section{Analysis of the Two-Stage Least Square (2SLS) and the Ordinary Least Squares (OLS) Methods}

The OLS linear regression assumes equation (2) to be a zero systematic error:

$y_{n}=\sum_{i=0}^{k} \beta_{i} x_{n i}+\varepsilon_{n}$

The matrix notation of $n .1$ and a vector notation of $n . k$ (the matrix); $k .1$ (vector); and the result is $n .1$.

n.1

where $\varepsilon[e]=0$

The $2 S L S$ implemented when some of the independent variables correlate with $\varepsilon_{-} \mathrm{n}$ and faces an endogeneity problem.

$\theta_{2 S L S}=\left(z_{p}^{\prime} Z\right)^{-1} Z_{p}^{\prime} y$

where $Z_{p}^{\prime} Z=Z_{P}^{\prime} Z_{p}$ which is the $O L S$ of y on $Z_{p}$.

\section{Variables}

This study sourced its data from the ((Central Bank of Nigeria (CBN), 2019), (Index Mundi (IM), 2019), and (CEIC, 2019)). The variables adopted for the empirical analysis includes the Unemployment rate $\left(U R_{t}\right)$, which is the explained variable in the base equation (8). $U R_{t}$ is defined as the number of people within the labor force who do not have jobs but are actively looking for one (source (IM, 2019)). Real Gross Domestic Product $\left(R G D P_{t}\right)$ an explanatory variable; it is the total value of economic output produced within any sovereign economy each year and adjusted for inflation (source (CBN, 2019)). Foreign Direct Investment $\left(F D I_{t}\right)$ an explanatory variable it refers to the total value of investment made in a country by a 
foreign government, agencies, or even multi-national corporations (source (IM, 2019). Population $\left(\right.$ Pop $\left._{t}\right)$ refers to the total number of people living within a geographical location (source (CEIC, 2019)). And inflation rate $\left(\operatorname{In} f_{t}\right)$ a dropped explanatory variable after a robustness test and model sensitivity test. $\operatorname{In} f_{t}$ is the rise in the general price level of goods and services in an economy, and " $t "$ " is the time from $1986-$ 2018.

\section{Model Specification}

The $O L S$ equation before the robustness and sensitivity test is:

$U R_{t}=\beta_{0}+\beta_{1} \ln R G D P_{t} \beta_{2} F D I_{t}+\beta_{3} \ln P o p_{t}+\beta_{4} \ln f_{t}+\omega_{t}$

And then operationalized to our base model as:

$U R_{t}=\partial_{0}+\partial_{1} \ln R G D P_{t}+\partial_{2} F D I_{t}+\partial_{3} \ln P o p_{t}+\mu_{t}$

Endogeneity exist between $U R_{t} R G D P_{t}$, and $F D I_{t}$. Hence, we predict $\ln \widehat{R G D} P_{t}$ using $F D I_{t}$ and $\ln P o p_{t}$.

$\ln R \widehat{G D P}_{t} \equiv \ln R G D P_{t}=\gamma_{0}+\gamma_{1} F D I_{t}+\gamma_{2} \ln P o p_{t}+\varepsilon_{t}$

\section{The Endogeneity Relationship}

According to Iloabuchi (2019), after analyzing the effects of the unemployment rate in Nigeria and economic growth, the author found that there is a unidirectional Granger causal relationship between unemployment and economic growth, supporting the assertion of endogeneity between $U R_{t}$ and $\ln R G D P_{t}$ in our study. Gross \& Ryan's (2008) paper that investigated the effects of employment projection laws and contract jobs on Japanese firm-level FDI in Western Europe in the ' 80 s' and ' $90 \mathrm{~s}$ ' find that these protections do matter in the location choice of Japanese investors and hurt FDI-related employment size. While (Fung et al., 1999) found that increasing FDI into a nation can affect the economic dynamics of a country positively and negatively, supporting the supposition of endogeneity between $U R_{t}$ and $F D I_{t}$ in our model.

Osiobe (2019) analyzed the effects of Australia's declining fertility rate and found an inverse relationship between fertility rate and income per capita and from the model used in the paper, there is a $0.11 \%$-point relationship between (Table 1 of the study), population and real gross domestic product per capita and population. This study can be used as a frame to defend the endogeneity relationship between UR_t and lnPop_t. To operationalize the base equation (6), we substitute $\ln R G D P_{t}$ with $\ln R \overline{G D P}_{t}{ }^{\wedge}$ as the new base model equation (8):

$U R_{t}=\delta_{0}+\delta_{1} \ln R \widehat{G D P}_{t}+\delta_{2} F D I_{t}+\delta_{3} \ln P o p_{t}+\varphi_{t}$

\section{Data Analysis and Results}

TABLE 1

SUMMARY STATISTICS OF THE VARIABLES (log)

\begin{tabular}{|c|c|c|c|c|c|}
\hline & $U R_{t}$ & $R G D P_{t}$ & $\mathrm{Pop}_{t}$ & $F D I_{t}$ & $\operatorname{In} f_{t}$ \\
\hline Mean & 9.37 & $\begin{array}{l}366.2 \\
(10.37)\end{array}$ & $\begin{array}{l}133151.3 \\
(11.76)\end{array}$ & 3120 & 19.92 \\
\hline Median & 9 & $\begin{array}{l}289.5 \\
(10.27)\end{array}$ & $\begin{array}{l}128667 \\
(11.76)\end{array}$ & 1880 & 12.22 \\
\hline Maximum & 22 & $\begin{array}{l}698.1 \\
(11.15)\end{array}$ & $\begin{array}{l}195875 \\
(12.19)\end{array}$ & 8840 & 72.84 \\
\hline
\end{tabular}




\begin{tabular}{llllll}
\hline Minimum & 1.9 & $\begin{array}{l}15237.99 \\
(9.63)\end{array}$ & $\begin{array}{l}85819 \\
(11.36)\end{array}$ & 193 & 5.38 \\
Std. Dev. & 5.61 & $\begin{array}{l}194.1 \\
(0.52)\end{array}$ & $\begin{array}{l}33008.99 \\
(0.24)\end{array}$ & 2590 & 18.29 \\
& & & & & \\
\hline
\end{tabular}

Source: Authors' calculation

$n=33$

\section{The Balance of Payment Account (BOP A/C)}

The $B O P a / c$ is a record of all payments or monetary transactions between a country and the rest of the world during a specific period. The equation for the $B O P a / c$ is:

$B O P A / C=$ Current Account $(C a / c)+$ Capital Account $(K a / c)+$ Financial $(F a / c)$

with the assumption/hope that:

$C a / c=K a / c+F a / c$

\section{Result Interpretation}

TABLE 2

2SLS RESULTS

\begin{tabular}{cllc}
\hline & Coefficient & T-value & P-value \\
$\ln \widehat{R G D} P_{t}$ & 13.47 & 3.53 & $0.00^{* * *}$ \\
$F D I_{t}$ & -1.98 & -1.09 & 0.28 \\
$\ln P o p_{t}$ & -7.46 & -2.65 & $0.01^{* * *}$ \\
& & & \\
Adj- $R^{2}$ & $20 \%$ & & \\
\hline $1 \% * * * ; 5 \% * * ; 10 \% *$ & & & \\
Authors' calculation & &
\end{tabular}

Table 2 shows our empirical findings. It can be inferred from the study that a $1 \%$ increase in $\left(\ln \widehat{R G D} P_{t}\right)^{\wedge}$ will lead to a $0.13 \%$-point rise in $U R_{t}$. According to Anyaehie \& Areji (2015), Nigeria is a mono commodity (petroleum) based economy and is plagued by the Dutch disease (Otaha, 2012). Due to the country's oil sector's heavy dependence on foreign experts, the energy sector exerts a significant influence on the nation's economy by acting as a prime mover. Hence, the country is in a vicious circle because it has zero competitive, comparative, nor price advantage of its main export (crude oil) and import (refined produce) (Ayadi et al., 2002). Our result implies that most skilled workers' jobs in Nigeria, especially in the oil industry, are handled by qualified experts (white-collar employees). These experts (in most cases in the oil industry) (Ogunwa, 2012) have little ties to the country hence, reducing their net Marginal Propensity to Consume (MPC) in Nigeria. This reduction in the foreign experts' MPC within the country, will have a net negative impact on the nation's economy (direct, indirect, and induced). As a result of this shift in capital flight and remittances, the net multiplier of money within the country will decrease, resulting in a reduction in the nation's Marginal Propensity to Save (MPS).

Subsequently, as capital flight and remittance for foreign experts continue to increase, the net demand for the naira in the money-market will reduce, causing the currency to lose its value while increasing the value of other hard currencies like the USD. Hence, fostering economic growth and development outside Nigeria. Studies like ((Ballard, 2003) (Siddique et al., 2012) (Fayissa \& Nsiah, 2010) (Pradhan et al., 2008) (Adams, 2006) (Adams \& Page, 2005) (Adam, 2011)) showed a positive impact on growth and reduced poverty in the developing world. At the margin, they spend less on consumer goods and more on investment goods like education and housing. Concerning this study, we associate the positive statistical relationship 
between $U R_{t}$ and $\left(\ln \widehat{R G D} P_{t}\right)$, with capital flight and the outflow of remittances through the $K a / c$ and $F a / c$ (see equation $9 \& 10$ ) via transfer payment and FDI to their friends, families, and lucrative businesses abroad. This analysis with the $B O P a / c$ is justified because it allows economists and policymakers to identify any long-run trends (jobless recovery) that could harm the economy.

Figure 3 shows the remittance flowing from the developed world to the developing world. The red and black parallel lines linked to the BOP a/c shows remittance movement from Nigeria to the rest of the world, and the redline indicates more FDI flows out of the country. According to the WDI (2019), global remittances flowing from high-income countries, reached 689 Billion (Bn) USD in 2018 up from 633 Bn USD in 2017. However, Nigeria has a high share of remittances as a share of GDP, which is $21 \%$ of its GDP (The World Bank Group, 2019). Ang (2007) analyzed the 3rd, largest recipient of remittances in the world after the nation India and Mexico, the Philippines who received about 11 Bn USD in 2005, which accounted for $10 \%$ of the nation's GDP. Aug (2007) confirmed ((Taylor, 2006) \& (Ballard, 2003)) presupposition that although remittance may contribute to economic growth, there is a need to create economic policies that promote active development in the region. Because, these remittances do not solve the problems of necessary infrastructure, access to credit, and other development problems.

FIGURE 3

\section{FLOW CHART OF REMITTANCES}

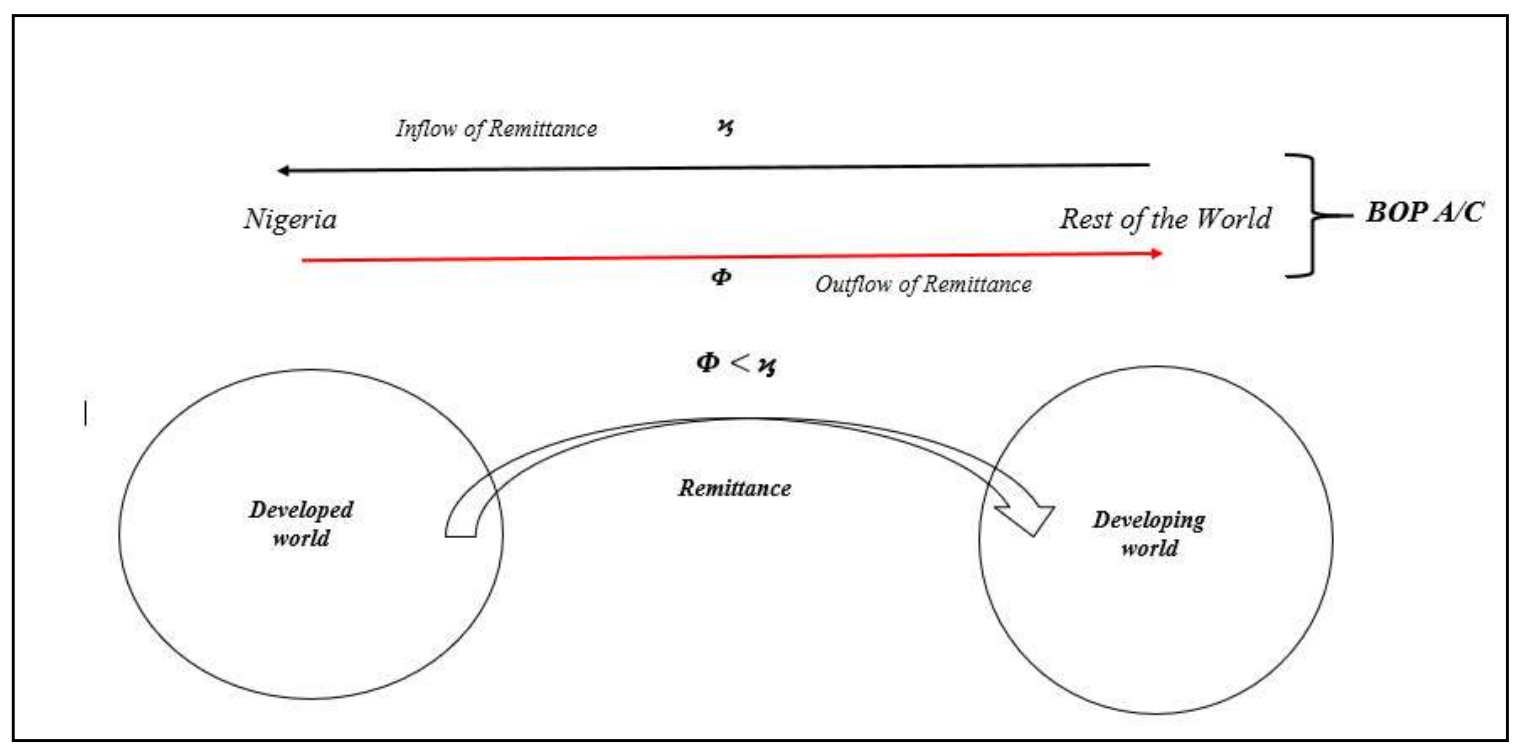

Source: Authors' creation

Our findings support those of (Leon-Ledesma \& Piracha, 2004), whose result showed the impact of remittances on unemployment depends on its effect on productivity growth and investment. The authors' analyzed 11 transition countries from 1990 - 1999 and found a positive impact on productivity and employment both directly and indirectly through its effect on investment. Javid et al., (2012) supports the finding that remittances have a substantial and statistically significant impact on poverty reduction, thus suggesting that there are significant potential benefits associated with international migration for poor people in developing countries like Pakistan.

Our results show that an increasing $\left(\ln \widehat{R G D} P_{t}\right)^{\wedge}$ will increase $U R_{t}$, which can be associated with an increasing capital flight and outflow of remittances from Nigeria, which is an emerging economy to the rest of the world. Ceteris Paribus, this implies that the foreign experts who work in the mono-economy, primary industry (the oil sector) with zero ties to the country; hence, they will send a large share of their net income to their home country. Thus reducing their overall net MPC and MPS, and increasing capital flight and outflow of remittances. Our results also show that a $1 \%$ increase in $\ln P o p_{t}$ will lead to a $0.75 \%$-point 
decrease in $U R_{t}$. This implies that as the fertility rate in the country increases, $U R_{t}$ decreases. The result can be explained using the steady-state, where all endogenous variables are constant

$\dot{c}=\dot{x}=\dot{\mu}=\dot{k}=\dot{l}=0$

Translating into our base-equation (7):

$\dot{c}=\dot{x}=\dot{\mu}=\dot{k}=\dot{l}=0$

Operationalizing to the golden rule as capital accumulates and population growth increases, Figure 4 is assumed, and it shows the effect of $\operatorname{lnPop} p_{t}$ on $U R_{t}$ at the steady-state. Where $R^{1}$ represents white-collar jobs, $R$ represents blue-collar jobs, $\tau^{1}$ represents white-collar-pay, $\tau$ represents blue-collar-pay, $Q$ is associated with $\tau, \mathrm{R}$, and $\dot{r}=0$ that shows the time reallocation towards white-collar jobs and away from the blue-collar jobs in the Nigerian economy justifying the saying that "monopolist never set the price in the inelastic range of the demand curve."

FIGURE 4

\section{STEADY-STATE AND THE DYNAMIC TRANSITION SYSTEM ASSOCIATED WITH $U R_{t}$ AND $\operatorname{lnPop}_{t}$}

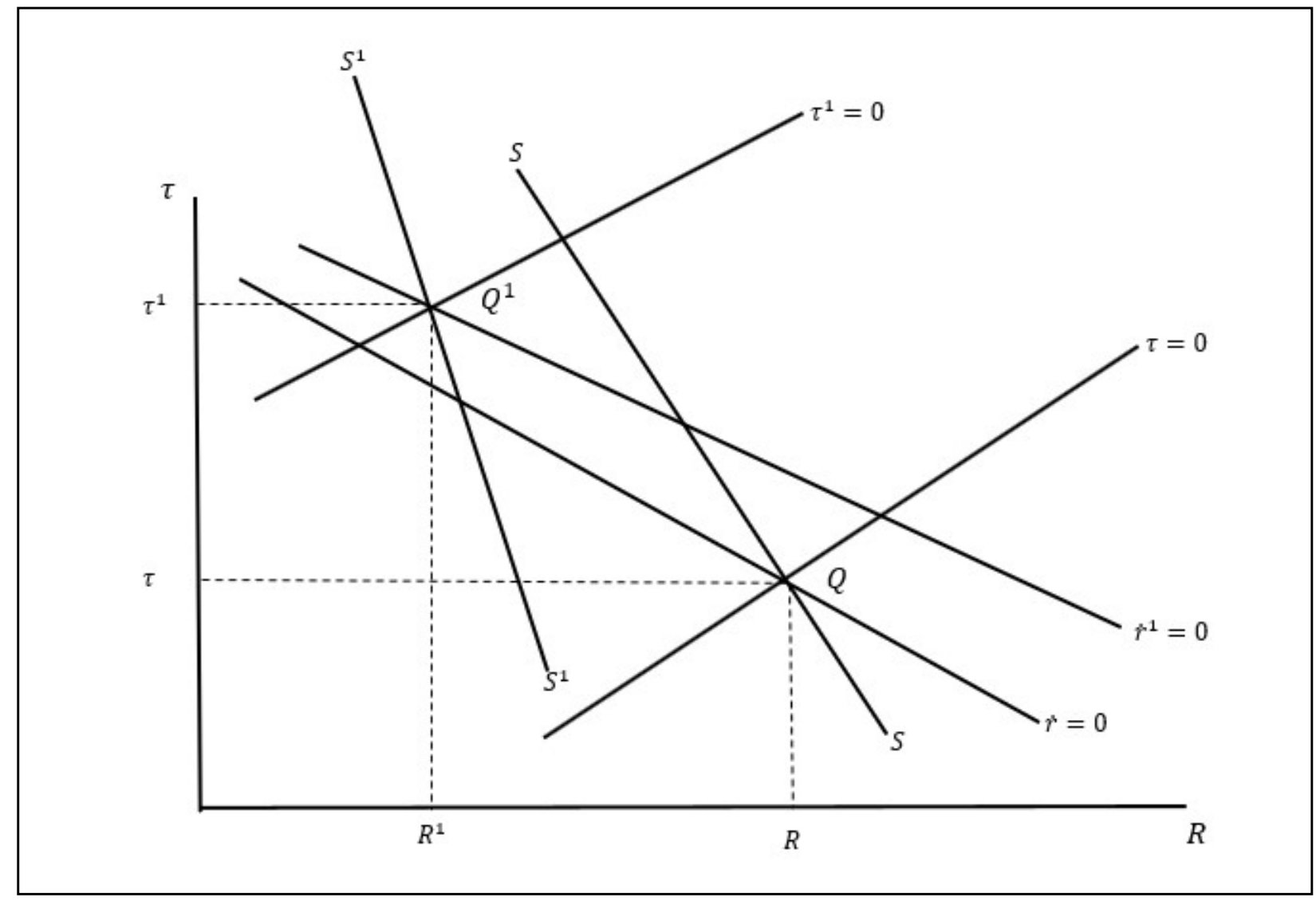

Source: Authors' creation

The deadweight loss as a result of this movement will result in higher pay for white-collar jobs, moving from point $\tau$ to $\tau^{1}$ which will increase the outflow of remittances and capital flight from Nigeria to the rest of the world. Thus, affecting the Nigerian job market, while the country's productivity level keeps rising, 
and the unemployment rate keeps increasing. On the other hand, blue-collar jobs will increase their supply, resulting in lower wages, which has a strong association with increasing MPC on consumer goods and decreasing MPS, which will create an intertemporal substitution effect that will reduce capital accumulation in the economy, reducing investment and productivity. Figure 4 assumes $S^{1}$ to be elastic and $\mathrm{S}$ is inelastic.

According to Wang et al. (1994), the sign of the correlation depends crucially on which shock initiates the motion on the relative reactive reactions of labor and capital stock input. The empirical evidence on the movement between the growth rate of Real Gross Domestic Product per capita and population growth has been inconclusive (Kormendi \& Meguire, 1985). Barro \& Becker (1989) examined how families and macroeconomy interreact, while (Becker et al., 1990) led the understanding of long term growth, and recognized much economic investment is directed towards human beings and physical capital.

\section{DISCUSSION, FINAL THOUGHTS, POLICY IMPLICATION, AND CONCLUSION}

\section{Discussion and Implication}

In the context of the base model (equation 8), the potential foreign expert may observe growing employment at home. Still, higher wages works are in the Nigerian oil industry as an expert (Figure $4 S^{1}$ curve) if allowed to move within a defined period, usually between (3-9 yrs). A traditional migration model will expect that at a time of low unemployment rate in one's country of origin, outmigration would increase, and immigration will decrease, but it is reasonable to assume that the potential immigrant (oil-foreignexpert) may feel more certain about the benefits of moving if they expect to return to their home country within a specified period. Hence, immigration increases, but so does capital flight and outflow of remittances (see Figure 4). According to Obeng-Odoom (2018), the major criticisms of modern-day mainstream development economics is that the industry does not provide an effective approach to studying inequality, and it is too Western-centric in both its concepts, methodology, vision of an ideal society. Some of the available analytical problems have contributed to worsening social conditions in Africa because they have shaped African development policies.

The relationship between RGDP and unemployment in emerging countries has been well debated. There are two views; the negative view holds that an increasing RGDP will increase unemployment, increase capital flight, and residents' dependency on remittances from friends and family working abroad. This scenario distorts the economic growth and development process since the animal spirit of the economy (optimism and pessimism), leans more pessimistic. The other view is that an increasing RGDP will reduce the unemployment rate, which is one of the critical factors in poverty alleviation, which is, growing the middle-class population. According to Leon-Ledesma \& Piracha (2004), the job structures and economic circumstances in each region differ. Migrants from relatively emerging to developed countries may perceive migration as enhancing long-term job prospects in any labor market through the acquisition of skills, experience, or the accumulation of savings, which will be used to finance future self-employment; through the creation of small businesses.

\section{Policy Recommendation and Conclusion}

Based on theoretical reviews, empirical reviews, and analysis, we recommend the implementation of the economic diaspora to stimulate economic growth and development in the country. For this paper, the economic diaspora will be defined as people who have roots from a particular nation either through ancestor or birth, but live in different parts of the world and have economic skills or finance that the country needs or outsource to the foreign experts. The opening of the People's Republic of China to the capitalist world led by President Jimmy Carter and Deng Xiaoping after 1979, was done in a spatial sequence designed to mobilize the resources of China, with the special economic zones located in crucial areas of migrant origins. Where most of the significant FDIs inflow that has come into China, has come from the Chinese diaspora (Smart \& Hsu, 2007).

Uduku (2007), analysis on how Igbo community, primarily the home town union/associations activities in the diaspora of the World Igbo Congress (WIC) have maintained links with the home town communities via fostering small and large-scale economic ventures, including but not limited to capital construction 
project, local investments, and occasionally local recruitment project for the international market from home towns (often small villages) in Eastern Nigeria. If other regions can imitate, not ignoring the remarkable efforts already made by local NGOs, these efforts will help flatten the $S^{\wedge} 1$ curve in (Figure 4), making it more inelastic. Vietnam's economic growth has implemented the returning diaspora more recently. Pham (2011) examined the recent government policy towards the Vietnamese diaspora, and the official contributions reveal that the economic diaspora used informal networks as their main route to make investments into the nation. Supporting our recommendation that will flatten the $S^{\wedge} 1$ curve (see Figure 4), the economic diaspora would be sufficient. Other countries that have practiced economic diaspora in recent times include, but are not limited to, India. The economic policies of the nation have undergone a paradigm shift (Kapur, 2004) analyzed the impact of transborder flows of ideas transmitted through international migration and return by Indian intellectuals and entrepreneurs on the policy preferences of governing elites.

Kapur (2004) argued that while these ideas transmitted are significant to growth and development, they are also the least evident. It is important to note that economic diaspora is not a fix-all pill to the jobless recovery state of the Nigerian economy but a step in the right direction. Other economic policies will need to support the initiative if implemented, like but not limited to the enforcement of the rule of law, property rights, and conversion of the democratic system from a nepotism system to a meritocracy system. With the economic growth in sub-Saharan African countries, Sub-Saharan Africa has experienced 20 years of virtually uninterrupted growth since the mid-1990s and combined with greater political and macroeconomic stability in the region. Economists and policymakers have expectations that this growth will lift the regions' bottom millions out of poverty by 2030 . This assertion is analyzed using three geo-socialeconomic success and region-specific-development trajectories 1) Britain's capital-intensive path, 2) Japan's labor-intensive way, and 3) Ghana's land-extensive growth path. The analysis in this paper has relevance even outside the context of the studies base model (equation 8) and underlining presupposition. For instance, our analysis impacts remittances, capital flight, migration, and consumption will contribute to testing the validity of the study.

Overall the empirical evidence from previous studies ((Graetz \& Michael, 2017) (Sanusi, 2012) and (Samauati \& Stumph, 2004)) on jobless recoveries supports the hypothesis that a non-linear dynamic relationship exists between output and unemployment. Our results show that an increasing $\ln R \widehat{G D P}_{t}$ will increase $U R_{t}$ and increasing $\operatorname{lnPop} p_{t}$ will decrease $U R_{t}$ at the $1 \%$ significant level. Our findings bridge the existing gap of western-centric approaches of locating these problems within the realm of ideas and look to the nexus between ideas, materialism, and history (Obeng-Odoom, 2018) while backing our finding with empirical analysis. Africa's poverty levels have steadily declined since the ' 90 s, and this progress has been driven by $G D P_{\text {per capita_ }}$ growth, which is consistent with the global evidence.

Inequality plays a complementary role in the rise of jobless recovery rate, poverty rate, and it is the primary driver of socio-economic changes in most developing and developed countries. Reducing inequality has increasingly become the main focus of economic growth, development, and economic stability, but poverty reduction is at the forefront of the development discourse in Africa. Although relative poverty has been on the decline in most countries, absolute poverty levels remain on the rise in Africa as population growth has been increasing exponentially, for example, Nigeria, which in turn has been offsetting the fall in poverty rates within the region.

Economists and policymakers agree that a higher pace of poverty alleviation programs will require a more intensive process of structural economic transformation that includes but are not limited to 1) increasing per capita productivity in agriculture, industry, and services sectors; 2) the transformation of per capita low productivity sectors into high productivity sectors (e.g., subsistence agriculture, informal economy); 3) a relatively egalitarian process between the poorest and affluence demographics of Africa. Existing literature suggests that countries' fundamental characteristics, growth, and redistributive policies are the underlining factors behind poverty reduction. Fosu (2015) has observed that the progress on poverty since the early-mid 1990s may be attributable primarily to income growth, presumably linked to the GDP growth resurgence. However, improvements in income distribution have been complimentary.

Today, compared to other sub-regions, the progress in sub-Saharan Africa (SSA) on poverty has been slow, and poverty levels remain relatively high (Thorbecke, 2013). The evolution of rural-urban exchange 
is not a linear growth trend. According to (Frankema \& Waijenburg, 2018), three generalizations are valid. 1) the current process of urbanization in Africa is stimulating economic growth via enhanced consumerside demand; 2) the agglomeration effects are raising labor per capita productivity by increasing division of labor and specialization, resource sharing, access to public goods, e.g., healthcare and education, and positive economic growth spill-overs; 3) the domestic market integration strengthens the forward and backward linkages between the agricultural, manufacturing, and service industries. Nigeria ranks among the bottom quintiles on the poverty gap. It squared poverty gap concerning the direct effect, redistribution of resources from the rich to the poor segment of society is likely to reduce poverty, even with a negligible growth (Bourguignon, 2003). But, according to (Fosu, 2015), inequality may or may not promote poverty reduction, depending on a country's level of income. While a reduction in inequality would generally decrease poverty, in developing countries, redistribution may exacerbate poverty.

Nevertheless, Nigeria has also grown tremendously in terms of $G D P_{\text {per capita }}$ (WDI, 2020), failed to generate a significant increase in income growth, presumably due to the dominance of capital intensive sectors (oil industry) in the country. Supporting the slope differentiation in (Figure 4) that at higher standards of poverty, greater efforts on growth and inequality reduction are required to alleviate poverty. While in many African countries, the poor seem to have benefited from economic growth, in other countries such as Nigeria, this trickle-down effect has been limited. One of Africa's growth and development central problem is that the very norm of economic growth and development, is not conceived of at the African level, but at the international level, by institutions such as the World Bank and the International Monetary Fund. The strategies for the continent's growth and development path are not empirically studied from primary data investigations from grass root researchers. Development is about the welfare and development of human capital which can be defined as education and training (formal, informal, and culture); knowledge; labor; skills (general, firm, job, and task-specific); experience (Osiobe, 2020) but, not just about RGDP growth. Development must not be limited to the stated definition, but, be centered around human capital while integrating his beliefs and relationship with his fellow man. That is, development should be the organic outcome of a people's value system, their perceptions, concerns, and endeavors with a path for the improvement and understanding of other cultures.

\section{Studies Limitation and Future Studies}

Although the data limitations constrained our empirical results and gave little space for further analysis, our results are theoretically consistent and statistically robust. The results of our findings display a negative relationship between $\ln R \widehat{G D P}_{t}$ and $U R_{t}$; a positive correlation between $\operatorname{lnPop} p_{t}$ and $U R_{t}$ within the Nigerian economy. Further research is necessary for analyzing the jobless recovery phenomenon by using different methodology and variables.

\section{Takeaways}

The overwhelming reliance on revenues from natural resource extraction (oil and gas industry) has stimulated the 'jobless recovery' epidemic in the nation and conspicuous consumption, and little expansion of employment in other industries with smaller profit margins. Scholars of different disciplines are divided about the extent to which recent growth is also driven by improved governance (Work, 2002), increased levels of education and investment (Osiobe, 2019 \& 2020), growing urban middle classes (Daramola \& Ibem, 2010), deepening financial markets (Onwumere et al., 2012), Information and Communication Technology revolutions/evolution (Ogunsola \& Aboyade, 2017), and rapid demographic growth as a result of major improvements in human health (Iwejingi, 2011). The current wage gaps between African economies and late industrializing countries in Asia, e.g., Vietnam, Bangladesh, and China, are not nearly as large as the gap between Britain and Japan around 1900. Hence, labor-intensive exported industrialization seems harder to realize for Africa in a world where Asian manufacturing is still building on its momentum.

This work addressed the jobless recovery phenomenon in Nigeria for which ongoing debates of why RGDP can lead to an increasing unemployment rate and how the federal government of Nigeria can implement the economic diaspora policy to foster economic growth, development, and reduce the 
unemployment rate in the region. This work has presented the 2SLS approach to address the jobless recovery phenomena in the country. Our paper can be used to provide valuable information to guide future researchers interested in this topic and policymakers when creating and implementing new and amending existing growth and development policies.

\section{Final Thoughts}

This paper investigated the effect of $\ln R \widehat{G D P}_{t}$ and $U R_{t}$ in the Nigerian economy. The authors' argument is based on theoretical and empirical backings. The results are inversely different (developed to emerging country) migration. But consistent with findings from previous works on the impact of RGDP and unemployment in the traditional economic growth theory in which economic growth and development are associated with a low unemployment rate. But the jobless recovery phenomenon does exist in Nigeria, and the paper's empirical findings provide evidence to the proposition.

\section{ACKNOWLEDGEMENT}

Dr. S.A. Osiobe funded this work and the contribution of the Ane Osiobe International Foundation in this project. As specified under the ethics statement of the Ane Osiobe International Foundation, Ane Osiobe Trendsetters series provides the public with transparent and unbiased information to help foster growth and development in Africa.

EUO supervised the analysis, interpreted the results analyzed, and wrote the paper. OMO downloaded and contributed to analyzing the data.

Stephen A. Osiobe, Ph. D., Hajiya-Idris Asma'u, and Nyore E. Osiobe

\section{REFERENCES}

Adams, R.H., Jr., \& Page, J. (2005). Do international migration and remittances reduce poverty in developing countries? World Development, pp. 1645-1669.

https://doi.org/10.1016/j.worlddev.2005.05.004

Adams, R.H. (2006). International Remittances and Household: Analysis and Review of Global Evidence. Journal of African Economics, pp. 393-425. https://doi.org/10.1093/jafeco/ej1028

African Development Bank Group. (2020, May 10). Nigeria Economic Outlook. Retrieved from https://www.afdb.org/en/countries-west-africa-nigeria/nigeria-economic-outlook

Ang, A.P. (2007). Workers' Remittances and Economic Growth in the Philippines. Dynamics Economics Growth, and International Trade Conference Papers.

Anyaehie, M.C., \& Areji, A.C. (2015). Economic Diversification for Sustainable Development in Nigeria. Open Journal of Political Science. https://doi.org/10.4236/ojps.2015.52010

Ayadi, F.O., Chatterjee, A., \& Obi, P.O. (2000). A vector autoregressive analysis of an oil-dependent emerging economy - Nigeria. OPEC Review, pp. 329-349. https://doi.org/10.1111/14680076.00087

Ballard, R. (2003). Remittances and Economic Development. International Development Committee: Evidence, pp. 157-168.

Banerjee, A.V., \& Duflo, E. (2011). Poor Economics: A Radical Rethinking of the Way to Fight Global Poverty. New York: Public Affairs.

Barro, R.J., \& Becker, G.S. (1989). Fertility choice in a model of economic growth. Econometrica, pp. 481-501. https://doi.org/10.2307/1912563

Becker, G.S., Murphy, K.M., \& Tamura, R. (1990). Human Capital, Fertility, and Economic Growth. Journal of Political Economy. https://doi.org/10.1086/261723

Bolt, P.J. (1996). Looking to the Diaspora: The Overseas Chinese and China's Economic Development, 1978-1994. Diaspora: A Journal of Transnational Studies, pp. 467-496.

https://doi.org/10.1353/dsp.1996.0019 
Bourguignon, F. (2003). The Growth Elasticity of Poverty Reduction: Explaining Heterogeneity across Countries and Time Periods. In T.S. Ericher \& S.J. Turnovsky, Inequality and Growth: Theory and Policy Implication. London: The MIT Press.

Brown, J.M. (2006). Global South Asians: Introducing the Modern Diaspora. Cambridge: Cambridge University Press. https://doi.org/10.1017/CBO9780511807657

CEIC. (2019, April 12). Retrieved from https://www.ceicdata.com/en

Central Bank of Nigeria. (2019, April 12). CBN-Data \& Statistics. Retrieved from https://www.cbn.gov.ng/documents/data.asp

Cheung, G.C. (2004). Chinese Diaspora as a Virtual Nation: Interactive Roles between Economic and Social Capital. Political Studies, pp. 664-684. https://doi.org/10.1111/j.1467-9248.2004.00502.x

Cohen, T., \& Moodley, L. (2012). Achieving decent work in South Africa? African Journal Online, pp. 320-344. https://doi.org/10.4314/pelj.v15i2.12

Daramola, A., \& Ibem, E.O. (2010). Urban environmental problems in Nigeria: Implications for sustainable development. Journal of Sustainable Development in Africa, pp. 124-145.

Enyinnaya, J., \& Osiobe, E. (2017). Cost-Benefit Analysis: The Ane Osiobe Altruism Farm of the Edison 3.0 Project 2017 Price Value. Abuja: The Ane Osiobe International Foundation.

Fayissa, B., \& Nsiah, C. (2010). The impact of remittances on Economic Growth and Development in Africa. The American Economist, pp. 92-103. https://doi.org/10.1177/056943451005500210

Fosu, A.K. (2015). Growth, Inequality, and Poverty in Sub-Saharan Africa: Recent Progress in a Global Context. Oxford Development Studies, pp. 44-59. https://doi.org/10.1080/13600818.2014.964195

Fosu, A.K., \& Gafa, D.W. (2020). Progress on poverty in Africa: How have growth and inequality mattered? African Review of Economics and Finance, pp. 61-101.

Frankema, E., \& Waijenburg, V. M. (2018). Africa Rising? A Historical Perspective. African Affairs, pp. 543-568. https://doi.org/10.1093/afraf/ady022

Fung, M.K-y., Zeng, J., \& Zhu, L. (1999). Foreign Capital, Urban Unemployment, and Economic Growth. Review of International Economics, pp. 651-664. https://doi.org/10.1111/14679396.00190

Graetz, G., \& Michaels, G. (2017). Is Modern Technology Responsible for Jobless Recoveries? American Economic Review, pp. 168-173. https://doi.org/10.1257/aer.p20171100

Gross, D.M., \& Ryan, M. (2008). FDI location and size: Does employment protection legislation matter? Regional Science and Urban Economics, pp. 590-605. https://doi.org/10.1016/j.regsciurbeco.2008.05.012

Iloabuchi, C.C. (2019). Analysis of the Effect of Unemployment on the Economic Growth of Nigeria. IOSR Journal of Economics and Finance (IOSR-JEF), pp. 82-89.

Indexmundi. (2019, April 12). Retrieved from https://www.indexmundi.com/nigeria/

International Labor Organisation. (2020, May 10). Decent Work. Retrieved from https://www.ilo.org/global/topics/decent-work/lang--en/index.htm

International Labor Organization. (2020, May 10). Decent work and the 2030 Agenda for sustainable development. Retrieved from https://www.ilo.org/global/topics/sdg-2030/lang--en/index.htm

Iwejingi, S.F. (2011). Population Growth, Environmental Degradation, and Human Health in Nigeria. Pakistan Journal of Social Sciences, pp. 187-191.

Javid, M., Arif, U., \& Qayyum, A. (2012). Impact of Remittances on Economic Growth and Poverty. Academic Research International, pp. 433-447.

Kapur, D. (2010). Ideas and Economic Reforms in India: The Role of International Migration and the Indian Diaspora. India Review, pp. 364-384. https://doi.org/10.1080/14736480490895723

Kormendi, R.C., \& Meguire, P.G. (1985). Macroeconomic determinants of growth: Cross-country evidence. Journal of Monetary Economics, pp. 141-163. https://doi.org/10.1016/03043932(85)90027-3

Leon-Ledesma, M., \& Piracha, M. (2004). International Migration and the Role of Remittances in Eastern Europe. International Migration, pp. 65-83. https://doi.org/10.1111/j.0020-7985.2004.00295.x

194 Journal of Applied Business and Economics Vol. 22(9) 2020 
Lever-Tracy, C., Ip, D., \& Tracy, N. (1996). The Chinese Diaspora and Mainland China. New York: St. Martin's Press, Inc. https://doi.org/10.1057/9780230372627

Levi, S.C. (2002). The Indian Diaspora in Central Asia and its Trade, 1550-1900. Brill.

Lucas, J.R. (1988). On the Mechanics of Economic Development. Journal of Monetary Economics, 22, 342. https://doi.org/10.1016/0304-3932(88)90168-7

Lucas, R.E. (1980). Methods and Problems in Business Cycle Theory. Journal of Money, Credit, and Banking, pp. 696-715. https://doi.org/10.2307/1992030

Mackett, O. (2020). The measurement of decent work in South Africa: A new attempt at studying quality of work. African Review of Economics and Finance, pp. 203-247.

Mackett, O. (2020). The measurement of decent work in South Africa: A new attempt at studying the quality of work. African Review of Economics and Finance, pp. 203-247.

Mankiw, N.G., Romer, D., \& Weil, N.D. (1992). A Contribution to the Empirics of Economic Growth. The Quarterly Journal of Economics, 107(2), 407- 437. https://doi.org/10.2307/2118477

Mbaku, J.M. (2020). Comment on 'Poverty in Africa: How have growth and inequality mattered?'. African Review of Economics and Finance.

Nwoke, C. (2020). Rethinking the idea of independent development and self-reliance in Africa. African Review of Economics and Finance, pp. 152-170.

Obeng-Odoom, F. (2015). Africa: On the Rise, But to Where? Forum for Social Economics, pp. 234-250. https://doi.org/10.1080/07360932.2014.955040

Obeng-Odoom, F. (2018). Critique of development economics. The Japanese Political Economy, pp. 5981. https://doi.org/10.1080/2329194X.2019.1617637

Ogunsola, L.A., \& Aboyade, W.A. (2017). Information and Communication Technology in Nigeria: Revolution or Evolution. Journal of Social Sciences, pp. 7-14. https://doi.org/10.1080/09718923.2005.11892487

Ogunwa, S.A. (2012). Globalization and Developing Countries: A Blessing or a Curse in Nigeria. Insight on Africa, pp. 1-18. https://doi.org/10.1177/0975087814411143

Onwumere, J.U., Ibe, I.G., Ozoh, F.O., \& Mounanu, O. (2012). The Impact of Financial Deepening on Economic Growth: Evidence from Nigeria. Research Journal of Finance and Accounting, pp. 6471.

Osiobe, E. (2019). Forecasting how Crude Oil Export is Changing the Dynamics of Nigeria's Economy 1970 -2030. Lead City Journal of The Social Sciences.

Osiobe, E.U. (2018). The National Economic Impact from Agriculture. Abuja: The Ane Osiobe International Foundation.

Osiobe, E.U. (2019). A Literature Review of Human Capital and Economic Growth. Business and Economic Research, 9(4), 179-196. https://doi.org/10.5296/ber.v9i4.15624

Osiobe, E.U. (2019). The Effect of Australia's Declining Fertility Rate 1978 -2016. International Journal of Human Resource Studies, pp. 95-100. https://doi.org/10.5296/ijhrs.v9i4.15717

Osiobe, E.U. (2020). Human capital, capital stock formation, and economic growth: A panel granger causality analysis. Journal of Economics and Business, pp. 569-582. https://doi.org/10.31014/aior.1992.03.02.221

Otaha, J.I. (2012). Dutch Disease and Nigeria Oil Economy. African Research Review, pp. 82-90. https://doi.org/10.4314/afrrev.v6i1.7

Pham, A.T. (2011). The Returning Diaspora: Analyzing overseas Vietnamese (Viet Kieu) Contribution toward Vietnam's Economic Growth. Political Sciences.

Pradhan, G., Upadhyay, M., \& Upadhyaya, K. (2008). Remittances and economic growth in developing countries. The European Journal of Development Research, pp. 497-506. https://doi.org/10.1080/09578810802246285

Romer, P. (1989). Human Capital and Growth: Theory and Evidence. NBER Working Paper No. 3173. https://doi.org/10.3386/w3173

Romer, P. (1990). Endogenous Technological Change. Journal of Political Economy, 98(5), 71-102. https://doi.org/10.1086/261725 
Safarai, S., Stern, M., Flusser, D., \& van Unnik, W. C. (1988). Chapter Thirteen: The Social and Economic Status of the Jews in the Diaspora. In S. Safari, S. Flusser, D. Flusser, sser, \& W.C. van Unnik, The Jewish People in the First Century (pp. 701-727). Brill. https://doi.org/10.1163/9789004275096_004

Samavati, H., \& Stumph, C. (2004). Do the Poor Get Poorer? Women, Children, and America's Jobless Recovery. Proceedings of the Midwest Business Economics Association, pp. 72-81.

Sanusi, A.R. (2012). Macroeconomic Policy, Output, and Unemployment Dynamics in Nigeria: Is there evidence of jobless growth? SSRN. https://doi.org/10.2139/ssrn.2135752

Sharma, K. (2010). The Impact of Remittances on Economic Insecurity. Journal of Human Development and Capabilities, pp. 555-577. https://doi.org/10.1080/19452829.2010.520923

Siddique, A., Selvanathan, E.A., \& Selvanathan, S. (2012). Remittances and Economic Growth: Empirical Evidence from Bangladesh, India, and Sri Lanka. The Journal of Development Studies, pp. 1045-1062. https://doi.org/10.1080/00220388.2012.663904

Smart, A., \& Hsu, J-Y. (2007). The Chinese Diaspora, Foreign Investment, and Economic Development in China. The Review of International Affairs, pp. 544-566. https://doi.org/10.1080/1475355042000241511

Taylor, E.J. (2006). International Migration and Economic Development. Turin: International Symposium on International Migration and Development.

The World Bank Group. (2019). Migration and Remittances: Recent Development and Outlook.

The World Bank Group. (2019, April 8). Record High Remittances Sent Globally in 2018. Retrieved from https://www.worldbank.org/en/news/press-release/2019/04/08/record-high-remittances-sentglobally-in-2018

The World Bank Group. (2020, March 14). The World Development Index. Retrieved from http://data.worldbank.org/country/nigeria

Thorbecke, E. (2015). Multidimensional Poverty: Conceptual and Measurement Issues. The Many Dimensions of Poverty, pp. 3-19. https://doi.org/10.1057/9780230592407_1

Uduku, O. (2002). The Socio-economic basis of a diaspora community: Igbo bu ike. Review of African Political Economy, pp. 301-311. https://doi.org/10.1080/03056240208704615

UNDP. (1993). Human Development Report: People's Participation. Oxford: United Nations Development Program.

Wang, P., Yip, C.K., \& Scotese, C.A. (1994). Fertility Choice and Economic Growth: Theory and Evidence. The Review of Economics and Statistics, pp. 255-266. https://doi.org/10.2307/2109880

Weller, M. (2014). The Battle for Open: How openness won and why it doesn't feel like a victory. London: Ubiquity Press. https://doi.org/10.5334/bam

Work, R. (2002). Overview of decentralization worldwide: A stepping stone to improved governance and human development. Philippine Journal of Public Administration, pp. 1-24.

World Development Index. (2019). GINI index (World Bank estimate) South Africa, Nigeria, Kenya, Ghana. Retrieved from https://data.worldbank.org/indicator/SI.POV.GINI?locations=ZA-MATN-DZ-EG-NG-KE-LR-SO-GH

World Development Index. (2020, April 9). Gini Index (World Bank Estimate). Retrieved from https://datacatalog.worldbank.org/gini-index-world-bank-estimate-1 